to recur in particular places, and if this statement is corroborated by further investigation, it will certainly form a presumption in favour of cancer being an infective disease A curative serum for carcinoma has not yet been discovered. Up to the present time surgical treatment yields the best results, and the earlier it is adopted the better. We look forward to the development of new methods of diagnosis, so that the surgeon may be able to recognise the seat and character of the disease in the incipient stage. The pathology and treatment of cancer still bristle with difficulties. We are anxiously waiting for more light, and we are ready to receive it from whatever quarter it may fall upon us. It is at least some satisfaction to know that many of the best pathologists and surgeons are diligently labouring in all parts of the world to unfold the mysteries which still surround this terrible disease.

Future Progress of Preventive Medicine.

During the last fifty years there has been a steady increase in the value of human life, and we can confidently hope that the health of the people of Great Britain will continue to improve. In the coming century a sirronger and broader warfare will be carried on against preventable disease; sanitary authorities will grow in wisdom and will more graciously accept their responsibilities; the public health service will be better organised; the medical officers of health will be better paid, and wholly devoted to their duties; hospital accommodation for contagious disorders will be considerably inereased ; and the houses of the working classes transformed and reconstructed on modern lines. I believe there is every reason to anticipate that the death-rate of the country may still be greatly reduced, and that io to 12 per 1,000 may be the figures of the coming century.

The great hindrance to the progress of preventive medicine which we have to overcome is the overcrowded and insanitary condition of the dwellings of the working classes. This is the field on which the great battle with infectious disorders will have to be fought out. Our warfare will not be directly with microbic life, but rather with the conditions in which specific organisms are grown. We want to see more progress in getting rid of the crowded and dirty courts in every city. We want to behold fewer of these revolting pictures of impurity and wretchedness herding together in the narrow avenue where the light of heaven strives in vain to pierce the patched and broken windows, and where the meridian beams struggle in vain to penetrate through the gloom and corruption of these denlike homes. These denlike homes are the archenemies of sanitary progress in all our great centres. Philanthropy has long pleaded for the removal of these great social evils; the voice of the medical profession has long sounded the alarm; but we are still waiting for the educated and wealthy classes of the community to catch the same inspiration, and to join in demanding more sweeping measures by which these nurseries of disease may be exterminated.

But the battle against disease and death will only end in disappointment unless we have something more than the force of legislation and the unceasing watchfulness of a complete sanitary system. The great mass of the people must become willing and active helpers; the fathers and mothers of our land must learn how to maintain the healthfulness of their homes, and the blinding forces of selfishness and ignorance must be replaced by the best and purest aspirations.

If we had the power of transforming the dwelling houses throughout the land, and of establishing everywhere a perfect system of drainage, and of securing for all an abundant supply of pure water, we should accomplish but little without the help of the people themselves. Depend upon it, the basis of national health is the personal cultivation of health. Wewant the fathers of England to be the enlightened sanitary officers of their own households. We desire to see a wider knowledge of the laws of health, and I hope the day is not far distant when they will be zealously taught in every school in the kingdom.

How little the working classes and operatives in our large cities appreciate the fact that the prevention of human suffering and the preservation of health are in a great measure within their reach. They have to learn that they lose both in physical development and vigour by too much toil and too fittle rest. They have to learn that rest is essential to overcome the strain of daily labour, and that personal cleanliness and temperance, and domestic sanitation lead the way to higher blessings. The weekly rest when rightly used gives another impulse to sanitary progress. It promotes purification of the body and cleansing of the dwelling. What washings and scourings, - what polishings and decorations herald its near approach! What an army of buckets and brushes and dust disturbers are called out at its coming; what floods of clean water are made to remove the accumulations of the week! Yes; the weekly rest falls like a reviving dew on the hot brow of industry; it stops the wheels of labour; it soothes the brain, gives rest to the hands, and calls forth the highest aspirations of human nature.

\section{ADDRESS IN MEDICINE}

BY

\section{Sir RICHARD DOUGLAS POWELL, Bart. M.D., F.R.C.P.,}

Physician in Ordinary to Her Majesty the Queen ; Physician to Middlesex Hospital.

At the Annual Meeting of the British Medical Association, held at Portsmouth, August, 1899.

RECENT ADVANCES IN PRACTICAL MEDICINE. THINkING over the best way in which to fulfil the task which I am honoured by the request of the Council to perform to-day, it occurred to me that a few remarks on the developments of medicine from one in the current of practical work might be more interesting and appropriate than any more exhaustive discussion upon some one topic. Such remarks must necessarily be incomplete and fragmentary, reminding the hearers of what they already know in detail, suggestive of the trend of medical opinion to-day, and perhaps reviewing some of the changes in doctrine and practice within recent times.

In the brilliant, interesting, and inspiriting address with which you, Mr. President, favoured us last night you sketched with a master hand the history of medicine in the last hundred years. A glorious history too, full of triumphs in the uphill fight against misery and disease. The masters in medical science are well known to us, their deeds are all recorded for our example; their lives were lived in the interest and satisfaction of an all-absorbing pursuit which rewards labour and saives or subdues its disappointments.

$\mathrm{As}$ in the past so in the future, medicine, whether as a philosophy or a science or a beneficent calling, promises ever to find employment for the most cultivated, the most practical, and the best ordered intellects of the time; and perhaps of no other profession can it be said that in the pursuit of it all its members of all degrees, by directly or indirectly ministering to the relief of human suffering, enjoy the same range and intensity of interest and satisfaction. At no time has medicine been better adapted for study as a philosophy or a pure science than at the present. At no previous period in its history could its branches and offshoots give better promise of bearing fruit for the good of humanity to those who with leisure and sufficient wealth should cultivate them with industry and scientific zeal. The roll of the Royal College of Physicians includes the names of several Fellows who may be regarded as philosophers rather than as practising physicians; others are directors of State or research medicine and by no one Fellow have the highest practical interests and philanthropic aspects of the medicine of to-day been more stimulated, encouraged, and promoted than by H.R.H. the Prince of Wales, who has recently honoured the College by allowing his illustrious name to be placed upon the roll.

We are certainly better equipped for exact diagnosis now than ever before, and possess a larger and a more precise knowledge of a greater number of diseases. It would be shameful if this were not so, but it must be conceded that medicine has shown no lack of industry in utilising every advance in science and art available to the purpose. There are still some members of this Association who may remember. the introduction of the stethoscope into practical use. Are there any now living who will witness its substitution by other instruments? That the stethoscope has passed the zenith of its popularity I do not doubt, and it may, in part at least, come to be replaced by other methods of diagnosis.

It is probable that the introduction of photography into 
clinical medicine, and the more general use of bacteriological examination and surgical exploration, may, for a time at least dim the prestige of auscultation and palpation in diagnosis. It should not be so. A great responsibility rests upon the teachers of medicine of to-day to keep up the refinements of auscultatory and tactile diagnosis with all the additional precision that instrumental education by graphic methods and surgical introspection will afford. The flexible stethoscope which has come almost exclusively into use within the last twenty years, although a valuable and convenient instrument, is not one calculated to advance the refinements of ausculiation. Whilst it intensifies sounds it practically obscures impulses. The delicate mechanism of the ear can appreciate through the medium of the rigid stethoscope shocks and impulses not to be recognised by the hand, and which are lost in transit through an elastic medium. Thus the sense of totch in auscultation is, if I may use the phrase, in a certain degree becoming lost to us. I have known the diagnosis of an aneurysm missed in this way, and many of the points in cardiac conditions, especially exaggeration or otherwise of beat, shock, and accentuation sounds, estimation of force, etic., are better recognisable with the rigid stethoscope. It is all-important, of course, to maintain our sense of proportion and comparison by adhering mainly to one instrument, but the tactile element in auscultation cannot be replaced by any equivalent means of diagnosis.

Happily we already see a revival of the appreciation of the pulse in practical medicine, an appreciation increased, not obscured, by the careful and detailed study and comparisons rendered possible by graphic recording methods, which very methods for a time threatened to discourage direct tactile observations. Except in the clinical wards and the physiological laboratory the day of the sphygmograph may be said to be already past, but for the purposes of exact instruction with regard to the palpable features of the pulse it and all allied instruments must ever remain invaluable. It is an instrument par excellence for the school in the hands of an expert rather than for ordinary clinical use. The clinical habit of listening to the heart, not only with the view of hearing morbid sounds but to estimate work value, is also of recent acquirement, and thus we are coming better to perceive the true function and value of instrumental methods to illustrate, record, and instruct in the more accurate use of our naked senses.

\section{The Clinical Thermometer.}

The late Sir William Jenner, my revered teacher, in an address before this Association thirty years ago classified the thermometer with the stethoscope in clinical medicine, yet but a few years before the instrument was looked at askance by the greatest of physicians. It is as important in bedside medicine to-day as the barometer and compass combined are in navigation, and where we are sometimes led astray by pyrexial charts it is not the thermometer that is at fault but our insight that is imperfect. Not long ago the thermometer came almost to be regarded as a divining rod and a sole and sufficient indicator in febrile 'affections, and the temperature mistaken for the disease has been pursued round the dial by antipyretic medication and measures to the spoiling of the chart, the detriment of the patient, and the disappointment of the doctor. It is only comparatively recently that we have fully recognised that it is merely the exuberances of temperature or the abnormal effects produced upon the nervous system of individual patients by temperatures otherwise normal to diseased conditions that can be wisely treated by antipyretics. A better knowledge of the habits and vital history of the micro-organisms upon whose doing pyrexial phenomena so largely depend informs us that their initial attack and greatest activity is at the lower ranges of temperature, and that the higher ranges, the results of such activity, are more or less inhibitive to their well-being; so that given a febrile disease, we must accept without necessarily interfering with a temperature normal to it. Thus we have often observed a pneumonia or an influenza treated too vigorously with pure antipyretics pursue an abnormally stormy and adynamic course.

Anomalous Fevers.

The clinical study of anomalous fevers has gradually convinced us that in their development and full activity specific poisons may overlap one another in the same illness; thus the typical crescendo temperature of the early period of an enteric fever may be masked by the fluctuating pyrexia due to the toxin of an associated sepsis, or by the more abrupt incidence of a pneumonic or a rheumatic fever, and it is only as the course of these overlapping complications draws to a close that the more continued latent fever dawns through their misleading perturbations. In the later periods of enteric fever, again, the pyrexial process is normally overlapped and modified by blood contamination from the intestinal lesions sometimes amounting to pyæmia. A rational treatment of specific diseases must be guided by the recognition of these superfactors. I would venture to say in this connection that the rational and most successful treatment of tuberculosis is for the most part unwittingly directed to attendant phenomena which are secondary, and which for brevity sake we call septic. Tubercle in tissues at rest and protected from impure atmospheric contamination tends to obsolescence; our antiseptic treatment and our pure-air methods are mainly operative against such secondary infections.

Although in the diagnosis of fevers we have still in the main to trust to the gradual evolution of the characteristic features of the primary or predominant disease, we have auxiliary tests of modern design-some purely chemical such as Ehrlich's, others furnished by examination with bacterial reagents, such as Widal's test in enteric fever; none of them quite crucial, but both, and especially Widal's, of considerable value in anomalous cases.

The Combination of Surgery with Medicine.

Time does not permit me to do more than allude to the wonderful accession to preciseness in diagnosis as well as in successful treatment that has become possible of late years from the developments of surgery under Listerian methods. Perhaps one could not suggest better illustrations of the value of combined surgery and medicine than can be found in the diagnosis and treatment of cases of impacted gall stones, renal calculi, appendix disease, obscure empyema, and sequestral lung disease, cases that but a few years ago involved months of suffering and a fatal issue, but which can now be explored with little danger, and often treated with complete success.

\section{BaCteriology.}

It must be confessed that bacteriology in its application to diagnosis and treatment in practical medicine is yet in its infancy; but it is a very robust infancy, full of promise, the complete fulfilment of which none of us will live to see. The bacterial origin of tubercle, anthrax, diphtheria, erysipelas, septicæmia, typhoid, malaria, influenza, has been revealed to us almost within the memory of the youngest here, and has already been, in many instances, fruitful in suggesting measures of prevention and treatment.

Bacteriology in all its departments is, and must ever remain, subject to expert investigation. It is impossible for the busy practitioner to find the time or to maintain the technical skill and apparatus necessary for trustworthy investigation. The various Research Associations have hitherto in part fulfilled the want and the bacteriological departments of our hospitals are steadily growing in importance and value; but it is to be hoped that the time will soon come when in every district throughout the country there will be in connection with the Public Health Department a bacteriological laboratory, where the ordinary, and even the extraordinary, clinical tests will be at the command of every practitioner at a moderate scale of fees. Those who possess the D.P.H. degree should be the qualified experts. In many districts these laboratories already exist, and they would probably all pay a remunerative interest upon public capital expended upon their upkeep.

It is a matter for congratulation to see the departments of research and clinical observation approaching to closer communion in our great hospitals, a co-operation which cannot but be to the great advantage of the physicians, and I venture to think scarcely less so to the research expert. We are thus acquiring daily a more accurate knowledge of organised poisons and we are interpreting better the phenomena they produce.

SUsoeptibility $v$. IMMUNITY.

I am inclined to think that we are also coming to recognise better the third circumstance which renders virulent the 
specific microbe to its host. It has long been clear to every observant physician. who has on the one hand even superficially kept in view the results of bacteriological inquiry and who has thought upon the incidences of such infective diseases as he happens to meet, that we carry about with us in our accessible mucous tracts in our naso-oral and respiratory passages and in our blood, amidst other unconsidered trifles and as yet unclassified germs, samples of the organisms specific to many diseases. We are tenanted by these varied organisms from time to time in small colonies or singly, rendered inert only through want of opportunity. The very careful observations of Drs. StClair Thomson and Hewlett recorded in the Medico-Chirurgical Transactions for 1895 show that there is a natural cleansing if not antiseptic secretion from the healthy nasal membrane which preserves it from contamination by the numerous organisms which abound in the nasal avenues, so that mucus taken from the central membrane of the nose in health may contain few or none. Other bacteria surround us on all sides and from time to time obtain a temporary but abortive lodgment within us: virulent catarrh, diphtheria, pneumonia, influenza, tubercle, erysipelas, perhaps rheumatism and probably in epidemic times some of the other infective diseases would be represented in one or other category amongst our domesticated or casual occupants. It is not however enough to have the poison germ on the one hand to acquire the disease on the other; there are intermediate or antecedent circumstances of dosage, acquired susceptibility or that subtle malformation of tissue in certain organs which is inherited, and renders them weak in resistance to certain forms of attack. Let a period of depression come over us, involving some slight change in our blood or tissues, some local or general alteration in our chemical or vital functions, and one or other of these organisms may receive the opportutunity for aggressive cultivation. We virtually know that this is so in the case of a common cold. Acquired by a momentary chill at an open door, or a wetting that would fail to affect us on the mountain side, such a catarrh becomes at once a highly contagious disease, and will "run through the house." There can be no doubt that the catarrh is associated with the cultivation of an organism; it is equally probable that that organism must have pre-existed in some part of the nasal surface. Does some vasomotory disturbance bring about the local conditions of increased heat and moisture needful for that particular form of microbic cultivation, or is it merely depressed vitality that makes the host susceptible? No one, so far as I am aware, has yet condescended to work out the bacteriology of a common cold. Yet it is the type of a large number of more important diseases, and carefully investigated it would, I believe, be fruitful in side-lights upon their etiology and prophylactic treatment.

Dr. Washbourn, ${ }^{23}$ with whom I was discussing this question the other day, referred me to a most interesting and suggestive inquiry which he had made with regard to a case of recurrent catarrh, apparently simple. I must refer to the paper which is very short (being a single inquiry) for details, but I may briefly say that in an apparently simple coryzal catarrh, a bacteriological investigation of the mucous discharges revealed the presence of characteristic influenza bacilli and of pneumococci. The patient, aged 35, had been subject to similar, or apparently similar, attacks so long as he could remember. He had also had many recognised attacks of mild influenza, and had been working at the bacteriology of pneumonia. There are many people of somewhat feeble vitality whose complaint is that they are constantly catching colds. Such attacks are due probably to the cultivation of suecessive crops of an ever-present organism. We have little power in attacking the organism; we might as well do battle with a sunbeam. Our treatment is to fortify the host, although, meanwhile, some local applications of a cleansing kind will in these, as in hay asthma, help to protect from the poison. Whatever the true bacteriology of a common cold may be, this humble malady is one of the most common starting points of more important respiratory diseases, both as regards initial and secondary attacks.

Some few years ago I saw in consultation a medical friend who had pneamonia of a pythogenic type; but in response to my inquiry about drains I was informed that he had been in the house for some years, that he had a healthy family of young children, and that he himself had been in perfect health until he went out thinly clad on a cold night and got definitely chilled. He died after the lapse of a day or two and on investigation a free communication was found to exist between the main drain and his surgery. This gentleman must for some months have been occupied by microbes which did not become operative under the control of a robust vitality until that vitality was temporarily impaired.

The tendency to rheumatism runs in families. It is hardly possible to conceive that chorea is not a manifestation of the rheumatic poison, which is most probably a micro-organism. A mental shock is the usual intervening etiological factor in chorea, which presumably weakens the resistance of the nerve centres upon which the toxic influence falls. It is hardly possible that the mental shock and infection should have coincided in time; until more exactly informed we can only provisionally assume that the infective agent was indefinitely pre-existent.

This intermediate 'quantity in infective disease requires to be yet more carefully thought out in regard to measures of prevention and even of treatment. Much has been done by physicians in the last generation in general preventive hygiene with regard to the diseases then recognised as specific before their knowledge of the virus of these diseases was so accurate as now. More may yet be done if with the growing. precision of our knowledge of the infective elements, we maintain our inquisitiveness as to the conditions under which they become operative.

\section{Serdm-Therapeutics.}

I am in no way competent to discuss the question of serum-therapeutics from the bacteriological side. I will only glance at it from the side of results achieved in the form of additions made, and others we may hope to make, to our therapeutics. It is already an immense achievement if we have acquired the knowledge that every infection requires a separately-prepared serum for its treatment. It explains. many of our failures, and gives promise of adding to our successes. It has for some time been recognised that infective endocarditis has a manifold microbic pathology-streptococcus, staphylococcus, pneumococcus, gonococcus, are some of the organisms concerned. It is useless to employ an antistreptococcus serum for a pneumococcus infection, and even the two organisms, streptococcus and staphylococcus, which seem to work most cordially in couples, require a separate treatment. Thus is in part accounted for the very poor success as yet achieved by the serum treatment of this and of some other maladies more or less allied to it. From the clinical side one would judge there to be very frequently more than one poison in association. This is certainly the case in many diseases, for example, in the third and often in the first stage of enteric fever, in the suppurative stages of tuberculosis, in scarlatina, and perhaps in gonorrhœal rheumatism In pneumonia again it is remarkable that in every variety of the disease, the sthenic, the asthenic, the typho-pneumonia the septic pneumonia, and the influenzal catarrhal forms the characteristic pneumococcus is invariably to be found, ${ }^{24}$ and this coccus may be the micro-organism conspicuously present in those secondary lesions with which pneumonia is often complicated, and which are attributed to it, such as empyema, infective endocarditis, etc. Yet there are, I think, good reasons to doubt whether the pneumococcus organism alone, unassisted by some of its pyogenic contrères, is ever able to bring about these secondary lesions which are usually attributed to it. We must push our diagnosis then further to include a recognition of the precise organism or organisms which have obtained lodgment in any given case. Unfortunately in the earlier stages at least of ulcerative endocarditis bacteriological investigation is by no means always successful in identifying the organism or indeed in recognising any organism, for with well-marked clinical features the specimen of blood examined may be sterile. We may yet for some time to come, therefore, as in complex cases of enteric fever, with which these cases are often confounded, have to rely upon the general clinical phenomena presented by the case and its history of attack in our attempt to identify the poison and in our endeavour to select the antidote.

Whilst the possibility of neutralising by appropriate treatment the specific poison in certain diseases will relieve practitioners of some anxiety, it cannot fail on the other hand 
to add much to the tension of their labours by requiring an earlier diagnosis, and by the great care needed to avoid accidents in the use of delicate organic fluids prone to contamination and decomposition. It is impossible that the treatment can be much developed in general use until abundant local centres are secured for the provision of materials of guaranteed purity.

It is curious and instructive to note that the two diseases in which antitoxins are of most approved value, namely diphtheria and tetanus, the bacillary cultivation is declared (Behring) to be limited to the seat of inoculation, the blood only being charged with their toxins. Whereas the mortality from diphtheria but a few years ago varied from 25 to 50 per cent., according to the severity of the epidemic, it has been reduced by the serum treatment to from 25 per cent. to 8 per cent. according to the severity of the case and the date of infection.

Unfortunately, we have not yet been supplied with any reliable antidote for the serum treatment of pneumonia. I was goodnaturedly twitted by some of my friends in their criticism of a book published eight years ago because I did not speak well enough of the then recent observations of the Drs. Klemperer on the serum treatment of pneumonia; but in a paper read before this Association in London five years later I could say no more, and to-day, although Pane's antipneumococcic serum will protect a donkey or a rabbit from the evil consequences of a strong dose of pneumococcus infection ${ }^{12}$ it has not as yet come into practical use in the human disease. I have recently tried it in two cases without result. This may be due to three causes. In the first place, it is difficult to use the serum early enough in the disease, and, secondly, the most severe cases in which alone at present one feels disposed to try the remedy ure most generally complicated with some other infection, so that the pneumococcus in the sputum does not signify the sole-perhaps not the most important-element of danger in the case. Thirdly, the doses employed by Dr. Pane have been very large, so large that one shrinks from introducing in such bulk an unknown or imperfectly accredited element into any case not already desperate. In the use of these very large doses, my friend Dr. Charles of Rome has suggested to me the introduction of the serum per rectum as a method which he has known to prove efficacious with other serums, the absorption being rapid and the serum being unchanged. As yet, however, the serum cannot be obtained in sufficient quantity for use in such large doses. In all probability the want of success, with casual exceptions, in the antitoxin treatment of erysipelas, puerperal fever, and allied affections, including infective endocarditis, may be similarly accounted for by the presence of more than one organic infection, thus requiring, as pointed out by Behring, Pfeiffer, and Kanthack more than one antidote. I cannot mention the name of Kanthack without deploring the loss which our profession and humanity at large have suffered through the early death while yet in full vigour and promise of work of this most able pathologist.

Preventive Inoculation.

It seems possible that we may look in the near future for considerable devclopment of preventive serum treatment in the prophylaxis of endemic diseases. Already within the past few months we have seen maturing towards successful action the researches of Haffkine and Wright and others on the means of procuring immunity from typhoid fever and plague in those regions of our world-wide empire in which as yet the sources of the infection are beyond our control. We are no doubt becoming more susceptible to specific infections from the very increasing purity of our sanitary home surroundings, and it may be the more necessary on this account to grant an artificial immunity for those about to proceed to less favoured regions and who would otherwise present, as it were, a virgin soil for microbic cultivation. Indeed, the whole question of antitoxin and serum-therapeutics has only within the last five zears become of practical interest to the physician; doubtless many mistakes will have to be retrieved, many apparent steps forward retraced, but we may expect every day to bring to light fresh developments in the sure advance of the new departure. It must be a matter of consolation to our ultra-humane friends to note that although some sacrifice and some suffering to animal life may be involved in the necessary experiments, countless dumb creatures as well as many mere human beings will thereby be saved from destruction.

The Prevention and Treatment of Tubrrcolosis.

Amongst the questions that have in the present year ripened considerably, and have been urged forward strenuously towards a final settlement, that of the prevention and treatment of tuberculosis has taken a very prominent place, and it is impossible not to allude to it here, although it will be the subject of a special discussion in the Section of Medicine. Truly a disease which still claims one-ninth of our mortality may well command our deepest interest. That much has been done to diminish our national liability to consumption by improved sanitation on general grounds by Parkes, Simon, Bowditch, Buchanan, Milroy, MacCormac, Smith, Greenhow, is evident by the gradual reduction of the mortality in the last half century from 38 to 14 per 10,000 living, ${ }^{29}$ or in proportion to the population for England and Wales by one half since $185 \mathrm{I}$ (Tatham). Even in comparing the quinquennium 1875-79 with that of twenty years before, Longstaff found that the mortality from phthisis at the ages between 5 and 35 had decreased by 15 to 28 per cent., and he could say in 1884 that "the decline of the deaths in recent years is chiefly to be attributed to a diminished number of deaths assigned to fever and phthisis."2 All this has been effected without direct reference to the special bacillus element in the disease, chiefly by amending those conditions to which I have alluded as being intermediate between the bacillus attack, of which most of these pioneers in tubercle sanitation knew nothing, and the illness of the patient.

It may, however, be urged with some justice that we in this country have been behind our Continental friends in grasping the full significance from a prophylactic point of view of the discovery of a definite infective bacillus element in the dis. ease which was made seventeen years ago, and anticipated seventeen years previously.

For our sins in this respect, and perhaps in part because there are political and commercial as well as human interests concerned in the further measures necessary, the question of the prevention of consumption, which should have been calmly and forcefully considered as heretofore by experts in human and veterinary medicine, has become the subject of popular agitation with all the reckless exaggeration and no little threatening of the social tyranny which such agitations tend to produce. The whole subject seems to me, however, to have been well and fully discussed by delegates from all parts of the world at the Berlin Congress, and I believe that the careful, temperate, and broad-minded summary of the proceedings added by Dr. Pye-Smith to the report of the British delegates will do much to bring the matter again within the sphere of sober practical work on the part of private medical men and the proper State departments.

That it is au fond a right grouping to place all the previously ascertained causes of consumption amongst the predispositions, and to regard the disease itself as produced by definite infection or contagion through the inhalation of sputum dust, or by the ingestion of tuberculous foods, has been accepted at least for the last ten years ; but we must not discontinue to attach a due importance to the other etiological factors because one of them may seem prima facie to be sufficient. To set heredity at nought, to regard climatic considerations as of no importance, and to state that the disease is always acquired by direct contagion or infection is, in my opinion, to ignore much that is true, and to magnify that which should be carefully guarded from exaggeration.

Thirty years ago Sir W. Jenner, in an address to the Epidemiological Society, declared the transmission of tuberculosis from parent to child to be one of the best-established facts in medicine. Jenner did not mean by this the actual transmission of tubercle, nor has anyone that I know of, in modern times at least, made any such contention; but that the susceptibility to become tuberculous runs in families, and this I must confess remains with me an unshaken belief. Take, for example, on the one hand, the striking account by Dr. Reginald Thompson ${ }^{28}$ of 80 families of consumptive parentage yielding 385 children of whom 194 became phthisical and 37 died in infancy, leaving only 154 exempt. Consider this in account with the unproven direct communicability of the disease to which I shall presently allude, as shown by the distribution 
of mortality amongst married people compared with their numerical liability as members of the general public, and the case for heredity as a predisposing cause of consumption is a strong one if not still " one of the best-established facts in medicine." We cannot, of course, prevent consumptive people from marrying; there are exceptional conditions under which they may rightly do so, but the advice of the family physician should be steadfast in discouraging such alliances, which are unfortunately often prolific. Life assurance offices, whose calculations are based upon experience, will probably wait for much further evidence against the heredity of phthisis before they will feel justified in accepting without surcharge the lives of those who present a consumptive family history.

We are all familiar with circumstances connected with the incidence of certain cases of tubereulosis which render it probable that they have been acquired by indirect contagion through the contaminated dust of dirty rooms, and know that under certain conditions of stagnant, dark surroundings a patient with advanced phthisis of unclean habits would cause local danger of tuberculous infection to his attendants and friends and to future occupants of the room. But except under such and similar almost experimental conditions the evidence of the contagiousness of phthisis is extremely slender.

It for instance has not been proved that tuberculosis is more prevalent amongst married than single people, and Dr. Longstaff ${ }^{27}$ has shown that normal coincidence would account for more than the deaths reported. Pulmonary consumption is comparatively rare before puberty, infantile mortality being almost exclusively from bowel consumption through milk infection. Tuberculosis is nearly twice as frequent amongst male as amongst female infants. The mortality from tuberculosis has diminished more greatly, by from one-third to one-fourth, amongst females than males above the age of 20 in the last 30 years (Hugh Beevor), ${ }^{28}$ when one would think that industrial, nursing, and indoor conditions generally would have told against the female in this respect. The records of the officials and servants of one of our largest consumption hospitals taken out for 50 years, including a period precedent to the use of any special preventive measures beyond those of ordinary sanitation show a death-rate not in excess of that of the ordinary population.

Whilst, therefore, on the one hand advising every ordinary measure of cleanliness, avoidance of dust, and proper disposal and dieinfection of sputum, we may, and indeed must, avoid all exaggerated statements calculated to alarm the public as to the contagion of phthisis. In respect of sanitary precaution I would instance the simple and efficient directions of the Medical Officer of Health for Brighton ${ }^{30}$ as being in most reassuring and refreshing contrast to the theoretical and alarming precautions printed for some other health resorts and published on no official authority. These directions are, I understand, privately sent through the medical practitioner to the person affected.

\section{The Soll a and Diseask.}

It is again difficult to recognise the striking testimony of such reliable observers as Middleton, Bowditch, and Buchanan as to the influence of a wet subsoil on the prevalence of consumption with the present view of the acquirement of the disease only by human and bovine infection. We must recall, too, to mind the enormous prevalence of bovine tuberculosis, not be it observed only among stall-fed, crowded, and insanitary cattle communities, but amongst animals under good open-air conditions. Do we not find in this prevalence of tubercle amongst pasture-fed cattle, and in the fact of the prevalence of the disease in localities with wet subsoils and deficient sunlight, ${ }^{29}$ some probability that the tuberculous organisms, like those of actinomycosis, tetanus and anthrax may have an independent and preparasitic existence, and that like malaria tuberculosis will probably be found to have a double origin from purely microphytic as well as from parasitic infection.

It is remarkable that two at least of the most deadly of disease microbes, tetanus and anthrax, should be normal inhabitants of the soil, and yet how comparatively scarce these diseases are, and, as regards one at least, how communicable. It would seem that, as is the case also probably with malaria, whilst the ultimate source of the disease is vegetation in the soil, yet a greater virulence and activity is attained, and for a short time maintained by cultivation in the human body, or in that of certain other warm-blooded animals. With regard to tuberculosis I would make this final remark: that whilst we may hope on the one hand by. further careful sanitation, by destroying and diminisbing the careless distribution of bacillary dust, and by withdrawing from human consumption tuberculous foods, still to effect a considerable inroad upon the remaining 14 per 10,000 mortality from consumption; we cannot afford; on the other hand, to withdraw or relax precautions dictated by observations, sound in themselves, although in some regards capable of amended explanation, or we may have to make some deductions from the two thirds diminution in mortality already achieved. In my belief there is a mephitic laboratory beyond our special control, yielding organisms ever ready to attack the unwary and those whose vitality is depressed. General sanitation and cleanliness is our first line of defence against them all. Wherever the conditions of insanitation, dampness, deficient sunlight, and the prevalence of favouring diseases are present there aggressive activity may be again looked for.

Table Indicating the Actions of Various Sera.

\begin{tabular}{|c|c|c|c|c|}
\hline & Bactericidal. & Antitoxic. & Prophylactic & References. \\
\hline Diphtheria ... & $N i l$ & Strongly* & $\begin{array}{l}\text { Decidedly } \\
\text { (similar to } \\
\text { tetanus) }\end{array}$ & $\begin{array}{c}\text { Behring, Cobbett } \\
\text { and Kanthack,? } \\
\text { Clinical Soc., } \\
\text { SimsWoodhead," } \\
\text { American Pedia- } \\
\text { trics Society.5 }\end{array}$ \\
\hline Tetanus & $\mathrm{Nil}$ & \begin{tabular}{|} 
To circulating \\
poison, thai \\
which is as yet \\
unfixed by the \\
tissues. More \\
promising in \\
early and less \\
acute cases. \\
Cerebral or \\
subdural in- \\
jection pre- \\
ferred
\end{tabular} & $\begin{array}{l}\text { Prophylactic } \\
\text { for tissues } \\
\text { as yet not } \\
\text { attacked } \\
\end{array}$ & ${ }_{\text {Köhler.7 }}^{\text {Roux and Borrel, }}$ \\
\hline $\begin{array}{l}\text { Septicamia } \\
\text { (streptococ- } \\
\text { cal and al- } \\
\text { lied affec- } \\
\text { tions, erysi- } \\
\text { pelas, puer- } \\
\text { peral fever, } \\
\text { etc. ... }\end{array}$ & Doubtful & Decidedly & Decidedly & $\begin{array}{l}\text { Bulloch, }{ }^{8} \text { Mitchell } \\
\text { Bruce, }{ }^{9} \text { Commis- } \\
\text { sion American } \\
\text { Gyn. Soc.,10 Pet- } \\
\text { ruschky. }{ }^{11}\end{array}$ \\
\hline Pneumonia .... & Probably not & $\mid \underset{\underset{N i l}{\text { Decidedly }}}{\text { (experiment. }}$ & $\begin{array}{c}\text { Decidedly } \\
\text { (experiment- } \\
\text { ally) } \\
\text { Decidedly }\end{array}$ & $\begin{array}{l}\text { Pane, Eyre and } \\
\text { Wa s h bour }{ }^{12} \\
\text { Mennes.13 } \\
\text { Sanarelli. } 14\end{array}$ \\
\hline Snake poison.. & & Antitoxic & Prophylactic & $\begin{array}{c}\text { Calmette } \\
\text { Delarde. }{ }^{15}\end{array}$ \\
\hline Leprosy & $?$ & (probably not) & $?$ & $\begin{array}{l}\text { Atherstone and } \\
\text { Black, }{ }^{16} \text { Herman } \\
\text { and Abraham, } \\
\text { Palakawski. }\end{array}$ \\
\hline $\begin{array}{l}\text { Botalismus } \\
\text { (meat }\end{array}$ & - & Antitoxic & Prophylactic & $\underset{\text { Kempner. }}{\text { Van }}$ \\
\hline $\begin{array}{l}\text { poisoning).. } \\
\text { † Plague }\end{array}$ & - & ? Slight & Decidedly & $\underset{\text { mow.22 }}{\text { Haffkine, }}$ \\
\hline $\begin{array}{l}\text { ¿Cholera } \\
\text { Anthrax }\end{array}$ & $\begin{array}{l}\text { Yes } \\
\text { Yes }\end{array}$ & $\begin{array}{l}\text { Not } \\
\text { Not }\end{array}$ & $\begin{array}{l}\text { Decidedly } \\
\text { Decidedly }\end{array}$ & $\begin{array}{l}\text { Haffkine } \\
\text { Haffkine }\end{array}$ \\
\hline
\end{tabular}

* N.B-Paralytic affections are apparently increased by the use of anti* N.B.- Paralytic affections are apparently increased by the use of antiparalysis occurs.

paralysis occurs. and are frequently manifold, so that for the present each case is more or and are frequently manifold, so that for the present each case is more or less experimental, and must be judged on its own merits until push dignosis to exact variety of organism or organismsinvalied. serum plague and

\section{REFERENCES}

1 Behring, Clifford Allbutt, 1 Behring, Clifford Allbutt, Medicine, Art. Serum Therapeutics. 2 Cobbett and Kanthack, Uber das Schicksal des Diptherie-toxins im Tierorganistoxin of Diphtheria, Trans. Clin. Soc., vol. xxxi, 1898. \& Woodhead, Proceedings of the Society of Medical Officers of Health, February roth, 189.9. ceedings of the Society of Medical Officers of Health, February Ioth, I899. Diphtheria in Private Practice, May 26th, 1896. ${ }^{6}$ Roux and Borrel, April, 1898. 7 Köhler, Zum gegenwärtigen Stand der Serumtherapie des 
Totanus, Münch. med. Woch., No. 46, 1899. 8 Bulloch on Streptococcus Pyogenes, Trans. Brit. Inst.' of Preventive Med., First Series, 1897; also Lancet, May and, 1896. 9 Bruce, Septicæmic Infection Treated with Antistreptococcic Serum, BRITISH MEDICAL JodRNAL, July 8th, 1899. 10 Committee of the American Gynæcological Society on Antistreptococcic Serum in Puerperal Sepsis, Phil. Med. Journ, June 3rd, 1899. 11 Petruschky, Uber Antistreptokokken Serum, Zcit. f. Hyg., xxii, 485. 12 Eyre and Washbourn, Experiments with Pane's Antipneumococcic Serum, Lancet, April 8th, 1899. 18 Mennes, Zeit. f. Hyg., Xxv, p. 413, 1897. 14 Banarelli, Sur l'Emploi du Sérum Curatif et Préventif de la Fiêvre Jaune, Ann. de $\boldsymbol{C}$ Inst. Pasteur. xii, 1898. 15 Calmette and Delarde, Ann. de l'Inst. Pasteur, $X, 12,1898$. 16 Atherstone and Black, Official Reports upon the Serum Treatment of Leprosy, Centralbl. $f$. Bakt., Bd. Xxiv, 178. 17 Herman and Abraham on a New Serum for the Treatment of Leprosy, Centralbl. f. Bakt., Bd. xxiv, 179. ${ }^{18}$ Palakawski, Deut. med. Woch., 1898, No. 37. 19 Van Ermenger, Zeit. f. Hyg., xxvi, ${ }^{1897 .} 20 \mathrm{Kempner,} \mathrm{Das} \mathrm{Antitoxin} \mathrm{des}$ Botalismus, Zeit. f. Hyg., xxvi. a Hafrkine, A Discourse on Preventive Inoculation delivered at the Royal Society. London, June 8th, 1899. 23 lemow, The Serum Treatment of Plague, Lancet, May 6th, 1899. Diousion,

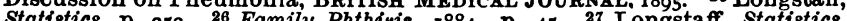
Statistic8, p. 252 . 26 Family Phthtsis, 1884, p. 45. 27 Longstaff, statistics, losis, p. 2, pp. 29, 33, 83. 30 Nowsholme, Lancet, February 4th, 1899

\section{ADDRESS IN SURGERY}

\section{ALEXANDER OGSTON, M.D.,}

Surgeon-in-Ordinary to Her Majesty the Queen in Scotland; Regius Pro. fessor of Surgery, University of Aberdeen.

At the Annual Meeting of the British Medical Association at Portsmouth, August, 1899.

\section{THE MEDICAL SERVICES OF THE ARMY AND} NAYY.

IN presence of an assemblage of so many representatives of the medical science of the British Empire, I have much pleasure in gratefully acknowledging the honour of being called upon to deliver the Address in Surgery. It is a task I enter upon with a sense of responsibility, and a fear lest I should fail to do justice to the duty entrusted to me by the Council of the British Medical Association. But I take courage from the belief that you will be disposed to form a lenient judgment of any endeavour to contribute to the usefulness of the annual meeting of our Association, and because I think that the theme I have chosen for the Address in Surgery on this occasion is one in harmony with the high aims of our science, since it has for its design to promote the great objects for which our profession exists, those, namely, of saving the lives and diminishing the sufferings of our fellow-men.

\section{A New Day in Surgery.}

At a time like this one cannot help being strongly impressed by the feeling that the surgical profession in our day has had much given to it, and that from it much will be required. We live in an era that can claim to be one of most exceptional probably unique, interest. We have witnessed in it the most marvellous and rapid advances the world has ever experienced in the powers of mastering and warding off disease. We have passed through many gloomy years, in which we worked our life's work blindly and in the dark, with dread fastening on the heart as surely as the hand grasped the knife, for ever trembling before the horrors of surgical pestilence; and now we have been privileged to see the dawn of a new day when septic disease is being robbed of its terrors by the discoveries of Lister, those great gifts to humanity, which coming generations will hereafter delight to recall, recognising that whatever we owe to the great surgeons of the past has been but little in comparison with the benefits he has conferred on us, and through us on all mankind. And we may be sure that future ages will be very critical in their judgment of us, the present race of surgeons, and demand to know what use we made of our unparalleled opportunities, and whether we went astray amidst all the light that was given us.

The Effect of Lister's Discoveries.

The importance of the period in which we live it would be difficult to exaggerate. For the first time in all the centuries that have flown our profession has changed from a craft into a science, a result that, though many have contributed to it, we owe mainlv to Lister. Every progress made in the years of my own professional life seems to dwarf before his great dis coveries, and imagination fails to grasp the limits and possibilities of the gigantic revolution which he commenced, or the unspeakable benefits it has conferred, and may yet confer, upon upon the world. The achievements of the surgeons before his day have now for the first time become fruitful and certain. Fresh fields of relieving and curing disease have been opened up at every point of our horizon, and in all the busy centres of the earth is springing up a new race of surgeons, who effect as part of their everyday work marvels of cure that even thirty years ago, had anyone ventured to forecast them, would have been looked upon as the dreams of a visionary.

It is not merely surgery that has undergone a revolution. The discoveries of Lister are changing the aspects of medicine, midwifery, pathology, and many other provinces of medical science, and creating new departments in them; they are, as they develop themselves, shaping our sanitation, our modes of life, our relations to the lower animals, and even raising questions that may profoundly affect the value of our colonies and dependencies. Year by year their power becomes more widely felt, and promises to extend yet further beyond what we can now foresee. But to follow out this train of thought would lead me astray from the practical purpose I have in view.

It is after all perhaps in our surgical hospitals, where they had their origin, that we witness some of the most impressive effects of Lister's doctrines. These homes of the sick poor have been reconstructed and reorganised in accordance with the principles he taught, until nowadays, in our own and in all civilised countries, the most advanced, the most deeply scientific, the most marvellous and delicate methods of cure are daily practised and placed at the service of our fellowcreatures. There is hardly anyone in this land, however humble and however poor, who, when stricken by a disease that modern surgery can grapple with, finds it beyond his power, if he possess the will, to convey himself to where some surgeon, skil!ed in all that is most powerful to aid him, may bid him be of good cheer, and hold out to him no doufbtful chance, but well-nigh the certainty of a safe and permanent cure of his malady. Those who live near the remoter districts of Britain, where men are few and help most distant, can best realise the influence of Lister and his teachings in bringing safety and cure within the reach of all, where before him no remedy existed.

It is moreover, I think, impossible to avoid the conviction that the open-handed beneficence we now witness in the increased interest and support extended to public charities in all their forms, by all the liberal and benevolent, from the artisan to the oocupant of the throne, has been in no small degree evoked by the great work he has enabled the surgical and nursing professions to carry out.

Are we now, however, with all this, in a position to look confidently around us and challenge the verdict of the world and of posterity on the use we are making of our increased knowledge? Have we done all that it is our duty to do? It is three-and-twenty centuries ago that the wise and practical old Greek wrote: "Medicine is of all arts the most noble ; but, owing to the ignorance of those who practise it, it is at present far behind all the other arts." We can picture to ourselves how great would be his rejoicing could the Father of Medicine see those things which we now see; but the reflection will obtrude itself at times like this, would such as he find us in all respects worthy of our opportunities?

Powers and privileges, bequeathed to a profession like ours, entail responsibilities which it is a sacred duty to fulfil, and this is felt and admitted by all the nations of the world who lead the van of progress. Our own country, which can boast of having produced the great reformer who is yet among us, witnessing the fruition of his work, is under a greater obligation than any other to profit by his discoveries; and it may be well, leaving the unalterable past that has gone from us, to make use of the present occasion to consider if we are sufficiently discharging our whole duty in this respect towards the immediate future, in which it is still ours to think and act.

The Unsatisfactory Condition of the Servichs.

While, in many respects, we have good reason to praise the age we live in, and the way in which it has availed itself of 